\title{
EVALUASI PASCA HUNI KEBERLANJUTAN PERUMAHAN MURAH TERHADAP PEGAWAI NEGERI SIPIL (PNS)
}

\author{
Fery Setyo Nugroho', Agam Marsoyo ${ }^{2}$ \\ Magister Perencanaan Wilayah dan Kota, \\ Universitas Gadjah Mada ${ }^{12}$ \\ e-mail: *1vrys.19@gmail.com
}

\begin{abstract}
In 2019, Indonesia was experiencing a housing backlog of around 7.6 million housing that must be met by providing new houses. Therefore there was a policy to overcome it through "one million housing" program. Salatiga City is one of the cities in Indonesia as a pilot project which has constructed provision of low-cost housing. While the current problem condition that happens is some facilities and infrastructure were unconstructed yet. Low-cost housing provision is just focused on housing units neglecting housing facilities and infrastructure that provided services for residents in post-occupancy. This research aims to assess the performance of residential housing and examine the gap factors influencing sustainability from a post-occupancy evaluation (POE) of low-cost housing projects. This research was conducted by assessing performance factors influencing sustainability by POE to value the quality of the residential environment. The result showed that factors including utility conditions; safety comfortability; social interactions; and access to workplace have good performance. While other factors have not met the score for good performance. This research has known that low-cost housing for civil servants can be said as unsustainable. The environmental aspect had an important role in the sustainability of low-cost housing. Building unit condition, infrastructure and neighborhood facility are factors with a big importance in influencing sustainability of environmental aspect. Therefore, these factors need to get the main attention in the government's next low-cost housing development projects in supporting one million housing program policy.
\end{abstract}

Keywords: Low-Cost Housing, Post-Occupancy Evaluation, Performance, Sustainability

\begin{abstract}
ABSTRAK
Pada tahun 2019, Indonesia memiliki housing backlog sebesar 7,6 juta rumah yang perlu diakomodir dengan pemenuhan perumahan baru. Oleh karena itu ada kebijakan melalui program "satu juta rumah." Kota Salatiga merupakan salah satu kota sebagai percontohan yang membangun perumahan murah. Namun kondisi yang saat ini terjadi, beberapa perumahan fasilitas dan infrastruktur perumahan belum terbangun. Perumahan murah ini hanya berfokus pada kondisi bangunan tanpa memperhatikan fasilitas dan infrastruktur skala lingkungan bagi penghuni setelah pasca huni. Penelitian ini bertujuan untuk menilai performa lingkungan perumahan dan menilai faktor kesenjangan yang mempengaruhi keberlanjutan perumahan dilihat dari Evaluasi Pasca Huni (EPH) dari proyek perumahan murah. Penelitian ini dilaksanakan dengan menilai performa faktor-faktor hunian perumahan yang mempengaruhi keberlanjutan dengan EPH untuk menilai kualitas dari lingkungan hunian tersebut. Hasil penelitian menunjukan bahwa faktor seperti kondisi utilitas; kenyamanan keamanan; interaksi sosial dan akses ke tempat kerja memiliki performa yang baik. Namun faktor lainnya tidak memenuhi performa yang baik. Melalui penelitian ini diketahui bahwa perumahan murah bagi PNS dapat dikatakan tidak berkelanjutan. Aspek lingkungan memiliki peran
\end{abstract}


penting dalam mempengaruhui keberlanjutan perumahan murah. Kondisi bangunan, infrastruktur dan fasilitas perumahan adalah faktor yang memiliki peran yang tinggi dalam mempengaruhi keberlanjutan, namun memiliki performa yang rendah. Oleh karena itu, faktor tersebut perlu mendapatkan prioritas utama dalam proyek pembangunan perumahan rumah murah oleh pemerintah pada tahap selanjutnya dalam mendukung program penyediaan "satu juta rumah".

Kata kunci: Perumahan Murah, Evaluasi Pasca Huni, Performa, Keberlanjutan

\section{PENDAHULUAN}

Pada negara berkembang, pertumbuhan penduduk perkotaan sering terjadi akibat urbanisasi yang menyebabkan kepadatan bangunan dan keterbatasan lahan (Daldjoeni, 1992). Perumahan harus dilihat sebagai kebutuhan dasar manusia yang menyediakan semua aktivitas masyarakat termasuk lingkungan fisik dan sosial dan masyarakat (Dwijendra, 2013). Aspek penting perumahan yang harus disediakan adalah keterjangkauan, kesesuaian dan keseimbangan permintaan pasokan yang berarti tidak ada backlog perumahan. Pada 2019, Indonesia memiliki backlog perumahan sekitar 7,6 juta (Kompas.com, 11 Maret 2019) yang harus dipenuhi dengan penyediaan rumah baru. Angka ini menunjukkan bahwa masih banyak masyarakat yang belum memiliki akses kepemilikan rumah dan kesulitan untuk memperolehnya (Bramantyo, 2012). Untuk memenuhi keseimbangan kepemilikan rumah, pemerintah terus menetapkan kebijakan pembangunan perumahan. Pada masa kepemimpinan Presiden Joko Widodo, pemerintah telah menetapkan kebijakan "satu juta rumah", terutama melalui pembangunan rumah murah dan pemberian subsidi bagi masyarakat berpenghasilan rendah, termasuk PNS yang belum memiliki rumah (Parmadi, 2018). Kota Salatiga merupakan salah satu kota di Indonesia sebagai pilot project yang telah membangun penyediaan rumah murah.

Pembangunan rumah murah bertujuan untuk memenuhi kebutuhan perumahan di Kota Salatiga bagi masyarakat berpenghasilan menengah ke bawah, khususnya bagi pegawai negeri sipil yang belum memiliki rumah di Kota Salatiga (Sunarti et al., 2018). Sedangkan kondisi permasalahan yang terjadi saat ini adalah beberapa sarana dan prasarana belum terbangun. Beberapa bangunan telah diubah dengan konfigurasi bangunan penuh (atau tanpa ruang terbuka) dan kurangnya akses transportasi umum.

Penelitian Ibem (2014) menyebutkan bahwa perumahan murah hanya terfokus pada unit rumah yang mengabaikan sarana dan prasarana perumahan. Kondisi ini mirip dengan proyek rumah murah di salatiga pasca huni. Oleh karena itu, penelitian ini melakukan evaluasi pasca hunian untuk melihat dan mengevaluasi keberlanjutan kinerja proyek rumah murah. Evaluasi Pasca Huni (EPH) adalah proses evaluasi yang digunakan untuk melihat kinerja suatu desain setelah bangunan dibangun dan dioperasikan oleh penghuni selama periode tertentu dengan fokus pada bangunan dan kebutuhan (Preiser, 1988). EPH memiliki keunggulan dalam mengidentifikasi dan mencari solusi permasalahan dari fasilitas yang ada di kawasan pemukiman. Penelitian terkait Evaluasi Pasca Hunian telah dilakukan terhadap penilaian dan pengukuran nilai kinerja bangunan setelah dihuni (Nawawi, 2008 dan Yuwono, 2016). EPH terkait perumahan dapat menilai green infrastructure areapermukiman (Lussetyowati, 2014). Sedangkan jika ditinjau berdasarkan keterjangkauan perumahan bagi masyarakat berpenghasilan rendah, EPH juga telah menilai kinerja tingkatkepuasan pada bangunan tunggal (vertical building) dan bangunan single use terhadap 
bangunan publik bersama seperti rusunawa (Sepriyadi, 2016 dan Hidayati, 2017). Sementara itu, Ilham (2008) mengulas pasca-hunian rumah tapak bagi masyarakat berpenghasilan rendah yang memiliki karakter kawasan yang lebih luas dan memungkinkan terjadinya perubahan kualitas fisik multihunian oleh individu pemilik rumah tanpa memperhatikan dimensi keberlanjutan. Studi lbem et al. (2015) tentang keberlanjutan perumahan rakyat menggunakan pendekatan EPH di Nigeria mengukur karakteristik fisik dan ekonomi dan menghasilkan keterjangkauan sebagai faktor berkelanjutan. Sementara itu, penelitian dengan menggunakan pendekatan EPH untuk melihat determinan keberlanjutan rumah murah di Indonesia belum banyak dilakukan. Oleh karena itu, penelitian ini akan melihat pasca hunian dari rumah tapak dengan perspektif keberlanjutan dan melihat gap pada faktor keberlanjutan yang terjadi. Selain itu, evaluasi pasca huni belum pernah dilakukan di Kota Salatiga. Sehingga perlu dikaji karena tidak menutup kemungkinan pembangunan dan penyediaan rumah murah bagi masyarakat berpenghasilan rendah akan dilakukan di bawah program kebijakan pemerintah saat ini, seiiring dengan program sejuta rumah untuk memenuhi kesenjangan pemenuhan kebutuhan rumah murah yang berkelanjutan. Tujuan dari penelitian ini yaitu untuk menilai kinerja perumahan perumahan yang mempengaruhi keberlanjutan dari evaluasi pasca hunian proyek perumahan murah. Signifikansi bagi bidang keilmuan yaitu memperkaya pengetahuan yang menghubungkan faktor pencapaian keberlanjutan perumahan murah di negara berkembang. Sedangkan untuk bidang perencanaan, sebagai masukan bagi badan perencanaan pembangunan perumahan yang dapat dijadikan sebagai kebijakan pemberian izin proyek perumahan baru.

\section{METODE PENELITIAN}

Pada dasarnya, penelitian ini bertujuan untuk mengkaji evaluasi pasca hunian lingkungan perumahan di Kota Salatiga dengan melihat kinerja fisik perumahan dan lingkungan sekitarnya; mengungkapkan kepuasan terhadap aspek sosial dan aspek ekonomi. Selain itu, penelitian ini juga membandingkan kondisi lapangan dengan kesesuaian standar yang ada dalam memenuhi kebutuhan penghuninya, apakah ada kesesuaian atau tidak yang akan menilai kelengkapan kualitas lingkungan perumahan. Penelitian ini akan menggunakan pendekatan positivistik dengan metode kuantitatif deduktif, yang pada intinya menekankan pada hal-hal yang bersifat konkrit, pengujian empiris dan fakta yang nyata. Selain itu penelitian ini juga menggunakan metode deskriptif yang bertujuan untuk menggambarkan apa yang terjadi di lapangan berdasarkan data di lapangan dan klasifikasinya. Pengumpulan data dalam penelitian ini dilakukan dengan dua cara, yaitu teknik pengumpulan data primer melalui observasi lapangan, angket dan wawancara penunjang, dan teknik pengumpulan sekunder melalui telaah dokumen. Variabel yang digunakan dalam penelitian meliputi dari aspek lingkungan, sosial dan ekonomi. Variabel dari aspek lingkungan meliputi kondisi unit bangunan, infrastruktur, utilitas dan fasilitas perumahan yang dinilai berdasarkan observasi lapangan dan penilaian kesesuaian standar. Varibel dari aspek sosial yang meliputi faktor keamanan kenyamanan, interaksi/ partisipasi sosial dan akses ke urban facilities dilakukan dengan kuesioner dan penilaian kepuasan penghuni perumahan. Variabel dari aspek ekonomi yang meliputi akses 
JournalHomepage: http://jurnal.ut.ac.id/reksabumi

http://doi.org/10.33830/Reksabumi.v

ke tempat kerja, biaya pemeliharaan/perawatan, dan asuransi/jaminan kepemilikan perumahan didapatkan melalui kuesioner dengan melihat kepuasan dan kondisi ekonomi penghuni perumahan. Dalam pengolahan data, untuk menganalisis kinerja EPH menggunakan nilai pembobotan dari hasil angket dan hasil observasi. Pembobotan akan diberi skor dari 0 sampai 1 . Misalnya dari parameter yang memberikan kondisi baik atau terpenuhi akan mendapatkan skor 1 . Kemudian kondisi cukup mendapat 0,5 dan kondisi buruk akan mendapatkan skor 0 . Dari masing-masing variabel akan dihitung skor rata-rata total sedangkan kategori baik memiliki nilai $66,7 \%$ - $100 \%$, sedangkan buruk memiliki nilai $0-33,3$.

\section{PEMBAHASAN}

\section{Profil Perumahan Murah bagi PNS di Kota Salatiga}

Prajamukti dan Prajamulya adalah perumahan murah yang diperuntukkan bagi pegawai negeri sipil yang bekerja di Kota Salatiga dengan persyaratan pegawai negeri sipil golongan II dan III yang belum memiliki rumah dan telah bekerja minimal lima tahun. Pembangunan perumahan ini bisa dikatakan sebagai salah satu pilot project di Indonesia yang memanfaatkan lahan milik Pemkot Salatiga untuk dijual kepada pegawai negeri sipil. Pemberian subsidi dilakukan dengan menekan harga rumah dari 120 juta rupiah (IDR) menjadi 83 juta rupiah (IDR) dengan skema pembiayaan hingga 15 tahun pembayaran. Perumahan Prajamukti dibangun di atas lahan dengan luas $59.207 \mathrm{~m} 2$, dimana $31.420 \mathrm{~m} 2$ (53\%) digunakan untuk kawasan perumahan, dan $27.787 \mathrm{~m} 2$ (47\%) digunakan untuk penyediaan infrastruktur, utilitas, dan fasilitas perumahan. Total luas unit rumah yang telah dibangun di Prajamukti adalah 400 unit. Sedangkan Prajamulya dibangun di atas tanah seluas $48.115 \mathrm{~m} 2$, dimana dokumen perencanaan luas $28.765 \mathrm{~m} 2(60 \%)$ digunakan untuk perumahan dan $19.350 \mathrm{~m} 2$ (40\%) digunakan untuk penyediaan perumahan infrastruktur, utilitas, dan fasilitas. Total unit rumah yang dibangun di Prajamukti sebanyak 375 unit. Prajamukti dan Prajamulya harus memiliki beberapa sarana dan prasarana pendukung dalam skala lingkungan satu perumahan. Sarana dan prasarana tersebut antara lain lapangan olahraga, tiga taman/ruang terbuka hijau, empat taman bermain, satu masjid, satu unit pengolahan air limbah komunal, satu minimarket, dan satu unit pompa air bersih. Namun, hingga saat ini, belum semua fasilitas yang direncanakan dibangun di kawasan perumahan ini. Beberapa fasilitas tersebut masih berupa tanah kosong yang status tanahnya milik Pemkot Salatiga.

\section{Gambar 1. Kondisi Eksisting Perumahan Prajamukti}
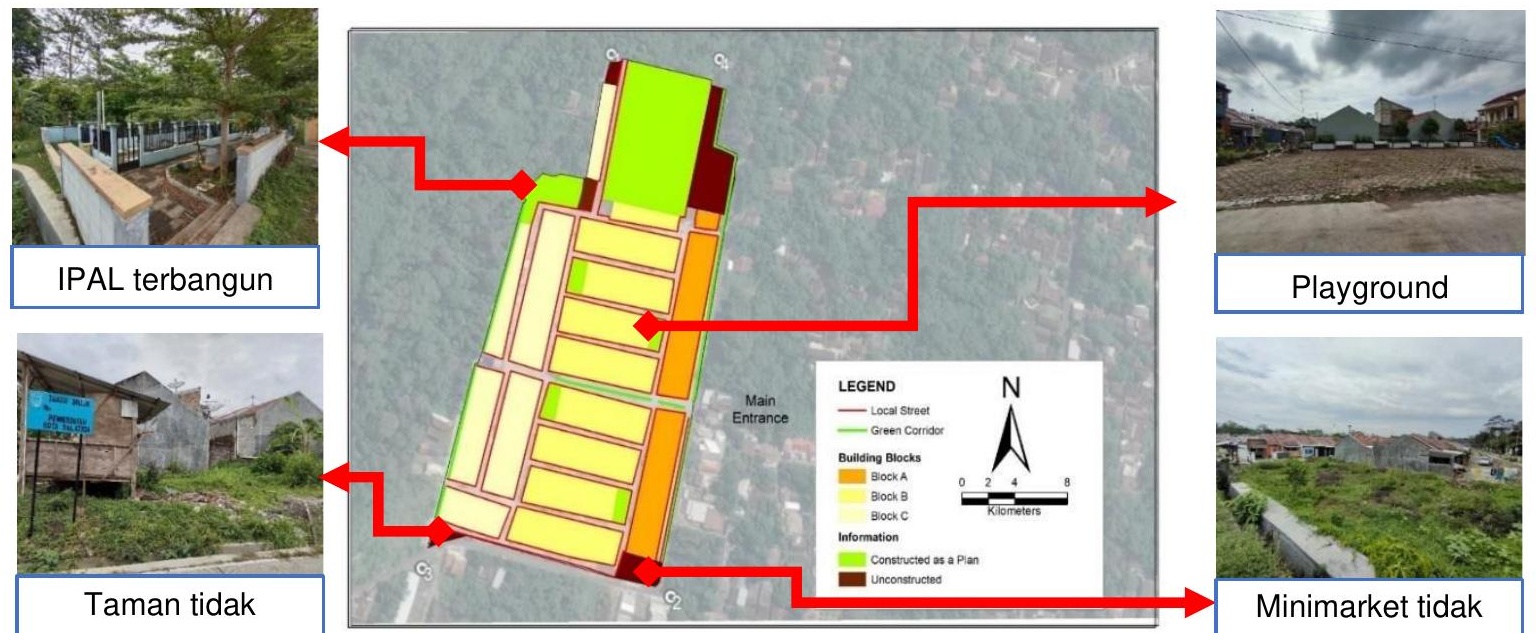


\section{Gambar 2. Kondisi Eksisting Perumahan Prajamulya}

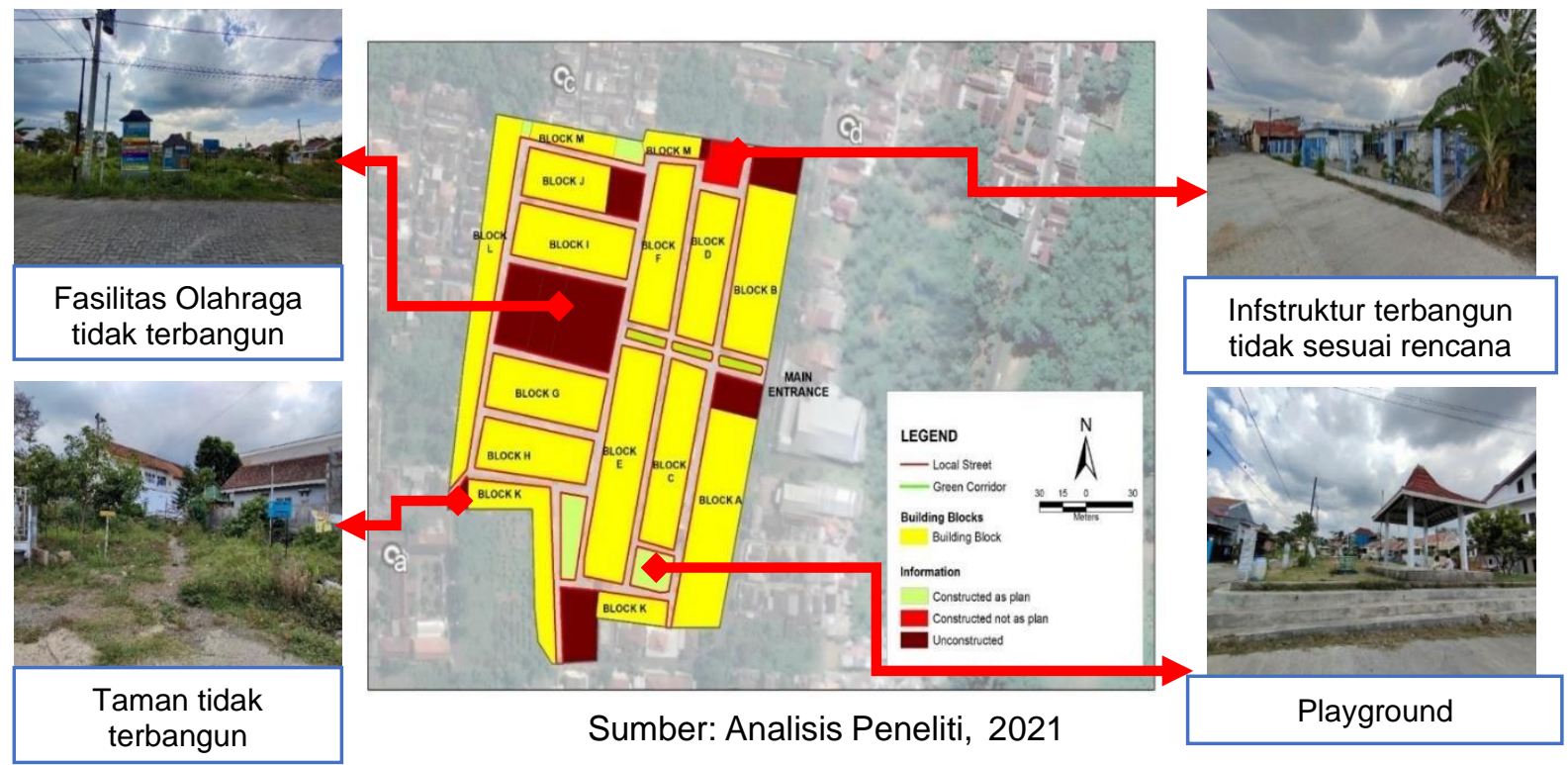

\section{Faktor-Faktor Keberlanjutan Perumahan Murah dari Aspek Lingkungan}

Aspek fisik dan lingkungan merupakan aspek terpenting dalam mempengaruhi keberlanjutan perumahan. Tupenaite (2017) menyatakan bahwa lingkungan merupakan kunci utama dalam pembangunan perumahan yang berkelanjutan. Namun, kelestarian lingkungan rumah murah di Kota Salatiga belum sepenuhnya terpenuhi sebagai berkelanjutan karena nilai kinerja rata-rata yang cukup memadai. Variabel yang digunakan untuk menilai kelestarian lingkungan antara lain bangunan perumahan, prasarana, utilitas, dan fasilitas lingkungan yang belum memenuhi standar kinerja yang baik.

\section{Gambar 3. Performa Faktor dari Aspek Lingkungan dalam Keberlanjutan Perumahan Murah}




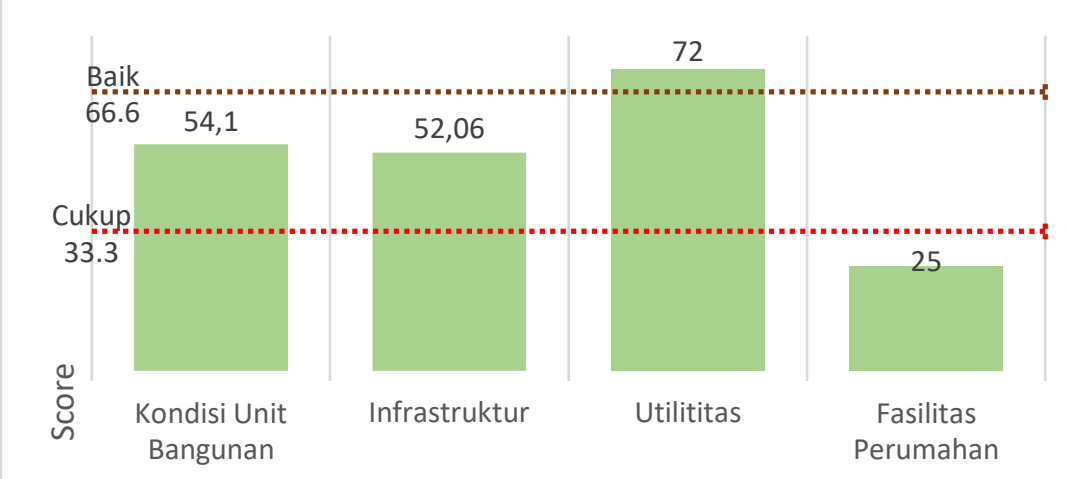

Sumber: Analisis Peneliti, 2021

Dari aspek lingkungan, hanya faktor utilitas yang mendapat nilai baik untuk kinerja berkelanjutan karena penyediaan air bersih dan jaringan listrik yang baik. Namun, tidak adanya hidran kebakaran mengurangi kinerja faktor utilitas di kawasan perumahan ini. Hal ini penting untuk perumahan murah karena kepadatan perumahan membuat rawan terhadap resiko kebakaran yang sangat tinggi di daerah tersebut. Kebakaran dapat diminimalisir dan ditangani dengan cepat dengan adanya hidran kebakaran sebagai sarana pengamanan kebakaran kawasan. Sedangkan kinerja terburuk dari aspek lingkungan dihasilkan dari fasilitas lingkungan perumahan. Kondisi ini menjadi buruk karena kurangnya akses ke taman bermain, ruang pertemuan, ruang parkir, dan pos keamanan. Pengembang kurang memperhatikan kelengkapan fasilitas lingkungan dalam menunjang kehidupan masyarakat. Sedangkan faktor Kondisi Bangunan dan Prasarana menunjukkan hasil yang cukup baik. Zhang et al. (2014) menyatakan bahwa pengukuran bangunan merupakan faktor penting dalam mempromosikan lingkungan yang lebih berkelanjutan.

Bangunan dalam kualitas dalam ruangan seperti kondisi pencahayaan dan ventilasi alami (Nilashi et al., 2015); kualitas luar ruang seperti ruang terbuka hijau dan cakupan koefisien dasar bangunan (Sudarwanto et al., 2014) merupakan variabel penting dalam mempengaruhi keberlanjutan perumahan. Variabel-variabel tersebut berkaitan dengan penghematan energi dari setiap unit bangunan yang ada. Keberlanjutan faktor kondisi rumah dan unit bangunan tidak terjadi pada perumahan murah PNS di Kota Salatiga karena kondisi bangunan memiliki nilai yang cukup. Banyak unit rumah yang telah direnovasi atau diubah total dari bangunan aslinya. Konfigurasi bangunan telah dikendalikan oleh pemilik dengan menyediakan sedikit ruang, bahkan tidak ada ruang terbuka yang tersisa di area lahan rumah pribadi. Padahal pada dasarnya dalam peraturan tata ruang (Rencana Tata Ruang Kota Salatiga, 2011), satuan bangunan harus menyisakan minimal 10\% ruang terbuka sebagai daerah resapan air dan penghijauan alami. Selain itu, perilaku pengelolaan sampah warga yang sebagian besar masih belum memilah sampah organik dan anorganik, menimbulkan ketidakberlanjutan skala unit rumah masing-masing.

Kondisi infrastruktur memiliki nilai kinerja yang cukup baik karena tidak adanya titik pengumpulan sampah di kawasan pemukiman. Keberadaan infrastruktur ini penting di kawasan pemukiman karena belum adanya pengelolaan kawasan dalam pengelolaan sampah lingkungan. Ada beberapa rumah tangga yang mencoba membuangnya sendiri ke tempat pengumpulan sampah terdekat. 


\section{๑ \\ JURNAL REKSABUMI}

JournalHomepage: http://jurnal.ut.ac.id/reksabumi
P-ISSN: 0000-0000 dan E-ISSN: 0000-0000

Volume 1 Nomor 1, Bulan Tahun, 01-22

http://doi.org/10.33830/Reksabumi.v

1i1.2155.2021

\section{Faktor-Faktor Keberlanjutan Perumahan Murah dari Aspek Sosial}

Perumahan harus dilihat sebagai proses hunian, termasuk lingkungan sosial dan masyarakat (Dwijendra, 2013). Aspek sosial dalam perumahan berkelanjutan memiliki peran penting yang akan mempengaruhi kualitas hidup dan mempengaruhi keberlanjutan lingkungan perumahan. Tujuan dari keberlanjutan sosial ini adalah untuk menciptakan masyarakat yang lebih harmonis, kohesif, dan berorientasi pembangunan satu sama lain (Chiu, 2006). Misalkan tidak ada keberlanjutan sosial yang baik di lingkungan perumahan, perilaku penghuni kawasan perumahan akan menjadi acuh satu sama lain, bahkan perilaku ini juga akan berdampak pada sikap tidak peduli terhadap lingkungan masyarakat dalam satu komunitas. Keberlanjutan ini dapat diciptakan melalui faktor sosial hingga lingkungan internal dan eksternal kawasan perumahan. Lingkungan eksternal dapat dilihat dari interaksi sosial individu di kawasan pemukiman terhadap fasilitas sosial eksternal dari suatu gangguan (Tanuwidjaja, 2009). Pada saat yang sama, aspek sosial internal adalah interaksi sosial individu di komunitas mereka dan tingkat masyarakat di mana penghuni merasakan dampak negatif dan positif tentang cara mereka bersosialisasi (Hashim, 2003).

Salah satu fungsi perumahan adalah memberikan rasa nyaman psikologis untuk mencari nafkah (Roestamy, 2017). Oleh karena itu, perumahan harus mampu memberikan rasa aman dan nyaman bagi penghuninya agar dapat terus berkembang dan memiliki privasi bagi setiap individu melalui ruang yang ada di dalamnya. Faktor kenyamanan dan keamanan perumahan murah bagi PNS mendapatkan kinerja yang baik. Faktor ini diperoleh dari persepsi nilai kepuasan penghuni terhadap pengalaman dan mengungkapkan perasaan penghuni selama pasca hunian terhadap kondisi lingkungan, kondisi tetangga, dan gangguan yang dialaminya. Namun, sebagian besar warga menerima lingkungannya dengan cukup baik tanpa gangguan atau ancaman. Selain itu, faktor interaksi dan partisipasi sosial juga memiliki hasil penilaian yang baik. Mereka saling bersosialisasi menjadi sebuah komunitas yang hidup berdampingan dan menciptakan harmoni sosial dalam skala lingkungan. Baik faktor internal yang berkaitan dengan keamanan maupun partisipasi sosial yang dihasilkan dari persepsi dan interaksi masing-masing penghuni rumah murah memiliki nilai yang baik. Namun faktor aksesibilitas terhadap fasilitas umum memiliki nilai kinerja yang cukup berkelanjutan. Seperti dalam penelitian Turcotte (2010) dan Ibem (2011) menyatakan bahwa pengembangan fasilitas lingkungan merupakan faktor yang kurang diperhatikan dalam menyediakan perumahan yang berkelanjutan. Sebaliknya, faktor ini merupakan salah satu faktor kunci untuk berkelanjutan. Kurangnya fasilitas lingkungan dianggap tidak dapat mengembangkan proses perumahan yang mandiri dan mandiri karena penghuni yang tinggal di dalamnya tidak akan berkembang secara sosial dan lingkungan tanpa fasilitas dukungan sosial dalam skala lingkungan.

Gambar 4. Performa Faktor dari Aspek Sosial dalam Keberlanjutan Perumahan Murah

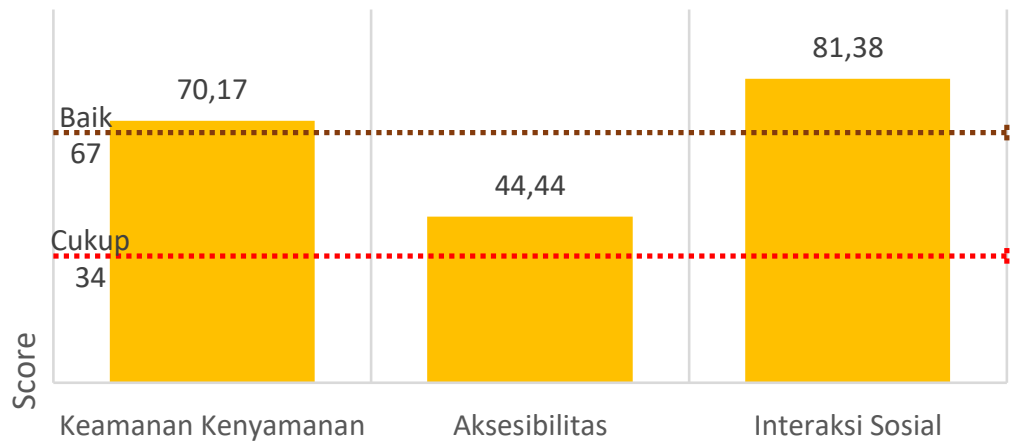


Pada perumahan murah di Kota Salatiga, rendahnya kinerja aksesibilitas dipengaruhi oleh minimnya aksesibilitas terhadap kesehatan masyarakat dan kawasan komersial. Pemilihan lokasi pembangunan rumah murah mempertimbangkan aspek lahan yang dimiliki oleh pemerintah sehingga dapat menekan harga jual properti yang lebih murah. Namun, pertimbangan ini telah mengabaikan aspek lokasi yang mampu menjangkau infrastruktur publik. Untuk mengatasi masalah aksesibilitas tersebut dapat dilakukan dengan menyediakan jalur angkutan umum untuk mempermudah akses terhadap prasarana umum. Namun, angkutan umum yang terintegrasi belum mampu menjangkau perumahan murah ke pusat kota dengan baik. Bahkan di Prajamukti, kondisi saat ini sama sekali tidak dapat diakses oleh akses transportasi umum ke daerah tersebut.

\section{Faktor-Faktor yang Mempengaruhi Aspek Ekonomi Keberlanjutan Perumahan}

Perumahan dapat dianggap terjangkau jika biaya bulanan untuk transportasi, biaya pelayanan, dan biaya perumahan tidak melebihi $30 \%$ dari total pendapatan (Miles et al., 2000). Dari sini dapat diketahui bahwa komponen cost at price yang dikeluarkan dari menghuni sebuah rumah akan mempengaruhi tingkat keberlanjutan ekonomi dari penghuni rumah itu sendiri. Seringkali biaya dalam perumahan sangat tinggi sehingga penghuni tidak dapat memenuhi pengeluaran lain selain pemeliharaan rumah (Ganiyu, 2016). Kondisi ini tentu mempengaruhi keberlangsungan ekonomi penghuni rumah itu sendiri. Keterjangkauan harga merupakan faktor yang paling signifikan dalam keberlanjutan ekonomi perumahan yang berkelanjutan (Mulliner et al., 2013). Pemerintah setempat telah menyediakan rumah murah bagi PNS ini dengan harga yang sangat terjangkau bagi pemiliknya. Apalagi, Pemerintah telah memberikan subsidi kepada pemilik dengan bantuan FLPP (Fasilitas Likuiditas Pembiayaan Perumahan). Sehingga faktor keterjangkauan rumah murah bagi PNS telah mampu memenuhi nilai yang baik karena adanya bantuan pembiayaan dari pemerintah, dan pembangunan rumah murah selalu mendapat bantuan subsidi dalam skema KPR dan pembayaran. Faktor lain yang perlu dikaji untuk aspek ekonomi pasca-hunian dalam penelitian ini adalah biaya-biaya yang dikeluarkan oleh penghuni selama pasca huni, antara lain akses ke tempat kerja dan biaya pemeliharaan/perawatan gedung. Akses ke tempat kerja memberikan nilai yang baik untuk keberlanjutan ekonomi. Sebagian besar penduduk telah menggunakan kendaraan pribadi untuk pergi ke tempat kerja mereka dan mereka berpikir bahwa lokasi untuk bekerja dapat dengan mudah dijangkau. Selain itu, biaya transportasi yang dikeluarkan oleh sebagian besar penduduk masih dianggap dalam batas wajar dimana sebagian besar penduduk masih mengeluarkan biaya transportasi kurang dari $10 \%$ dari total pendapatan bulanan mereka. 


\section{Gambar 5. Performa Faktor dari Aspek Ekonomi dalam Keberlanjutan Perumahan Murah}

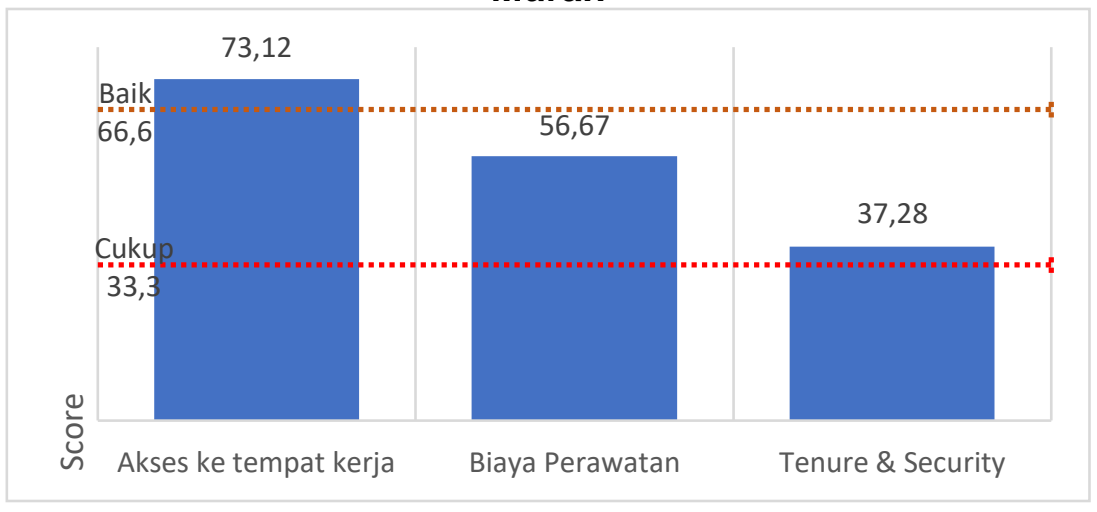

Sumber: Analisis Peneliti, 2021

Faktor biaya dan pengeluaran perawatan di perumahan ini bisa dibilang kurang berkelanjutan karena banyaknya kasus perbaikan yang dilakukan warga selama tinggal, yang memaksa warga untuk membayar biaya perbaikan bangunan yang rusak. Keawetan kualitas bangunan itu sendiri menjadi kunci keberlanjutan aspek ekonomi pasca hunian. Untuk menciptakan keberlanjutan pembangunan perumahan itu sendiri harus dilakukan dengan manajemen yang baik dengan pemilihan material lokal dan teknologi yang baik tanpa mengurangi kualitas bangunan itu sendiri (Tam, 2011). Namun kenyataannya, banyak warga yang melakukan perbaikan terhadap bangunan yang rusak di rumahnya. Faktor tenurial perumahan juga memberikan nilai yang kurang berkelanjutan dalam aspek ekonomi karena banyak penghuninya yang bukan pemilik rumah melainkan penyewa. Kondisi ini menunjukkan bahwa penerima bantuan rumah murah ini telah menyalahgunakan manfaat yang mereka dapatkan dari program rumah murah bagi pegawai negeri sipil. Selain itu, banyak pemilik rumah yang tidak memiliki pertanggungan asuransi rumah yang dapat menjamin keamanan rumah di kemudian hari, mengingat kawasan perumahan murah merupakan kawasan padat bangunan dan rentan terhadap risiko bahaya kebakaran.

\section{KESIMPULAN}

Kota Salatiga merupakan salah satu kota di Indonesia sebagai pilot project yang telah membangun penyediaan rumah murah dan disubsidi oleh Pemerintah Kota Salatiga, yaitu Prajamulya dan Prajamukti. Pembangunan tersebut dilakukan dalam rangka memenuhi keterjangkauan kepemilikan rumah. Sasaran kepemilikan rumah adalah pegawai pemerintah daerah kelas menengah ke bawah yang berpenghasilan di bawah rata-rata dan belum memiliki rumah. Prajamukti dan Prajamulya sudah berdiri sejak 2013. Artinya, sudah lebih dari lima tahun warga menempati perumahan tersebut. Namun kondisi permasalahan yang terjadi saat ini adalah beberapa sarana dan prasarana belum terbangun. Beberapa bangunan telah diubah dengan cakupan bangunan penuh (atau tanpa ruang terbuka) dan kurangnya akses transportasi umum. Penelitian ini telah melakukan penilaian dengan melihat pasca-hunian dari rumah tapak murah dengan perspektif keberlanjutan. Melalui 
penelitian ini, juga dilakukan pengujian terhadap gap factor yang mempengaruhi sustainability dari evaluasi pasca huni proyek rumah murah oleh pemerintah untuk PNS dengan melihat kinerja dan pentingnya faktor sustainability bagi keberlangsungan rumah murah. perumahan di Kota Salatiga. Pembangunan rumah murah di salatiga belum bisa dikatakan berkelanjutan. Aspek lingkungan merupakan faktor yang paling dominan mempengaruhi ketidakberlanjutan. Faktor penghambat kinerja keberlanjutan aspek lingkungan adalah kondisi bangunan perumahan, infrastruktur, dan fasilitas lingkungan. Faktor penghambat dari aspek sosial adalah aksesibilitas terhadap fasilitas umum, karena tidak adanya akses transportasi umum yang mendukung penduduk. Faktor penghambat dari aspek ekonomi adalah biaya pemeliharaan dan kepemilikan rumah.

\section{REFERENSI}

Apparicio, P., and Seguin, A. 2006. Measuring the Accessibility of Services and Facilities for Residents of Public Housing in Montreal. Urban Studies, 43(1), 187-211. DOI: https://doi.org/10.1080/00420980500409334.

Bramantyo. 2012. Efektivitas Regulasi Perumahan Di Indonesia Dalam Mendukung Penyediaan Rumah Bagi Masyarakat Bepenghasilan Rendah (MBR)/ Effectivity of Housing Regulation in Indonesia to Support Housing Provision. Widyariset, 243-248.

DOI: http://dx.doi.org/10.14203/widyariset.15.1.2012.243-248.

Budihardjo, Eko dan Sujarto, Djoko. 2009. Sustainable City. Bandung: PT. Alumni.

Bratt, Rachel G. 1989. Rebuilding a Low-Income Housing Policy. Philadelphia, the USA: Temple University Press.

Cao, J., and Cao, X. 2017. Comparing Importance-Performance Analysis and Three-Factor Theory in Assessing Rider Satisfaction with Transit. Journal of Transport and Land Use, 10(1). DOl:https://doi.org/10.5198/jtlu.2017.907

Chiu, Rebecca L.H., 2006. Socio-cultural Sustainability of Housing: a Conceptual Exploration. Theory and Society, 21:2, 65-76. DOI:10.180/14036090410014999

Coulson, N. E., \& Fisher, L. M. 2009. Housing Tenure and Labor Market Impacts: The search goes on. Journal of Urban Economics, 65(3), 252-264.

DOI:http://dx.doi.org/10.1016/j.jue.2008.12.003.

Daldjoeni, N. 1992. Seluk Beluk Masyarakat Kota. Bandung: Penerbit Alumni.

Dwijendra, Ngakan Ketut A. 2013. Quality of Affordable Housing Projects by Public and Private Developers in Indonesia: The Case of Sarbagita Metropolitan Bali, Indonesia. Journal of Geography and Regional Planning, vol.6(3), pp. 69-81, 2013.

DOI:10.5897/JGRP12.050.

Gan, X., Fernandez, I.C., Guo, J., Wilson, M., Zhao, Y., Zhou, B., Wu, J. 2017. When to Use What: Methods for Weighting and Aggregating Sustainability Indicators. Ecological Indicators, 81, pp. 491-502. DOI:https://doi.org/10.1016/..ecolind.2017.05.068

Gan, X., Zuo, J., Wu, P., Wang, J., Chang, R., Wen, T., 2017. How Affordable Housing Becomes More Sustainable? A Stakeholder Study. Journal of Cleaner 
Production 162

(2017),

$\mathrm{pp}$.

$427-$

437.

DOI: https://doi.org/10.1016/j.jclepro.2017.06.048

Ganiyu, B., Fapohunda, J., Haldenwang, R. 2015. Construction Approaches to Enhance Sustainability in Affordable Housing in Developing Countries. Conference: 2015 World Congress on Sustainable Technologies (WCST), pp 101-107. DOI:10.1109/WCST.2015.7415129

Gibson, R. B., Hassan, S., Holtz, S., Tansey, J., Whitelaw, G. 2010. Sustainability Assessment: Criteria and Processes. London, UK: Earthscan.

Goldie, A. G. S., R. U. Farhoudi, Ezat and A. Ezati. 2015. The Study of Effective Factor in Sustainable Urban Renewal Process (Case Study, IRAN; Mashhadcity). Research Journal of Fisheries And Hydrobiology 10(13): 15.

Habitat, UN. 2012. Sustainable Urbanizing in Asia, A Source Book for Local Goverment, United Nations Human Settlements Programme.

Hamedani, A. Zeinal and Huber, F. 2012. A Comparative Study of DGNB, LEED and BREEAM Certificate Systems in Urban Sustainability. WIT Transactions on Ecology and The Environment, Vo. 155 pp. 121-132. DOI:10.2495/SC120111

Hashim, A.H. 2003. Residential Satisfaction and Social Integration in Public Low Cost Housing in Malaysia. Pertanika Journal of Social Science and Humanity 11(1) 1-10.

Hidayati, Masturina K. (2017). Evaluasi Pasca Huni Pembangunan Rusunawa di Kota Surakarta. (Thesis). Yogyakarta: Universitas Gadjah Mada.

Ibem, E.O. and Azuh, D.E. 2011. Framework for Evaluating the Sustainability of Public Housing Programmes in Developing Countries. Journal of Sustainable Development and Environmental Protection (JSDEP). 1(3), pp 24-39.

http://eprints.covenantuniversity.edu.ng/id/eprint/745

Ibem, Eziyi. O. 2013. Accessibility of Services and Facilities for Residents in Public Housing in Urban Areas of Ogun State, Nigeria. Urban Forum, 24(3), 407-423. DOI:https://doi.org/10.1007/s12132-012-9185-6.

Ibem, Eziyi O., Aduwo, Egidario B., Ayo Vaughan, Emmanuel K. 2015. Assessment of the Sustainability of Public Housing Projects in Ogun State, Nigeria: A Post Occupancy Evaluation Approach. Mediterranian Journal of Social Science MCSER Publishing, Rome-Italy Vol 6 No.4 S2 pp 523 - 535, July 2015.

Doi:10.5901/mjss.2015.v6n4s2p523.

Ilham, Novri. (2008). Evaluasi Pasca Huni Lingkungan Perumahan Mojosongo Solo.

(Thesis). Yogyakarta:Universitas Gadjah Mada.

Indrianingrum, Lulut. 2017. Housing Ownership and Affordability Among Low-Income Society in the Poorest Sub-District of Semarang, Central Java, Indonesia. AIP Confrerence Proceedings 1818, 020019. DOI:https://doi.org/10.1063/1.4976883. Iwamura, Kazuo. 2017. Sustainability of Housing, Embedded in the Local Context. Yokohama: Faculty of Environmental and Information Studies, Tokyo City University. 
Kompas.com. "Per 8 Maret 2019, Backlog Rumah 7,6 Juta unit”. 11 March 2019. Retrieved from https://properti.kompas.com/read/2019/03/11/104252821/per-8-maret-2019backlog-rumah-76-juta-unit?page=all

Kuswartojo, Tjuk. 2005. Perumahan dan Permukiman Indonesia. Bandung: ITB.

Lussetyowati, T. 2014. Evaluasi Purna Huni pada Ruang Terbuka Publik di Perumahan Bukit Sejahtera Palembang. Proceeding Temu IImiah IPLBI 2014 pp. 19-26.

Martilla, J. A., and James, J. C. 1977. Importance-Performance Analysis. Journal of Marketing, 41(1), 77-79. DOI:10.2307/1250495

Meir, Isaac A. and Cicelsky, Alex. 2009. Post-Occupancy Evaluation: An Inevitable Step Toward Sustainability. Advances in Building Energy Research 2009, Volume 3 pp. 189-220. DOI:10.3763/aber.2009.0307

Miles, M.E., Weiss, M.A., and Berens, G. 2000. Real Estate Development: Principles and Process, $3^{\text {rd }}$ ed. Washington DC, USA: Urban Land Institute.

Mulliner, E., Smallbone, K., Maliene, V. 2013. An Assessment of Sustainable Housing Affordability Using a Multiple Criteria Decision Making Method. Omeg, 41, pp 270279. DOI: https://doi.org/10.1016/j.omega.2012.05.002

Nawawi (2008), Abdul H. 2008. Post-Occupancy Evaluation Correlated with Building Occupants's Satisfaction: An Approach to Performance Evaluation of Government and Public Buildings. Journal of Building Appraisal 4(2) pp 59-69. DOI:10.1057/jba.2008.22

Nilashi, M., Zakaria, R., Ibrahim, O., Majid, M.Z.A., Zin, R.M., Chugtai, M.W., Abidin, N.I.Z., Sahamir, S.R., Yakubu, D.A. 2015. A Knowledge-Based Expert System for Assessing the Performance Level of Green Buildings. Knowledge-Based Syst, 86, 194-209. DOl:https://doi.org/10.1016/i.knosys.2015.06.009

Odebiyi, S.O. 2010. Sustainable Housing Development in Africa: Nigerian Perspective. International Business and Management (1) pp. 22-30.

DOI: http://dx.doi.org/10.3968/j.ibm.1923842820100101.005

Parmadi, A.A. 2018. Implementasi Kebijakan Program Rumah Bersubsidi di Kecamatan Banjar Kabupaten Buleleng. Public Inspiration: Jurnal Administrasi Publik Vol 3 pp.34 - 45.

Peraturan Daerah Kota Salatiga No.4 Tahun 2011 Tentang Rencana Tata Ruang Wilayah Kota Salatiga 2010 - 2030

Peraturan Menteri Perumahan Rakyat no 25 tahun 2011 Tentang Pedoman Penyelenggaraan Rumah Murah.

Preiser, W.F.E, Robinowitz, H.Z, and White, E.T. 1998. Post Occupancy Evaluation. Ney York: Von Nortstand Reinhold Company.

Rahman Abdul, H., Wang, C., Ebrahimi, M. 2016. Integrating and Ranking Sustainability Criteria for Housing. Proceedings of the Instituion of Civil Engineers-Engineering, Vol 169 pp. 3-30. DOI: https://doi.org/10.1680/ensu.15.00008 
Roestamy, Martin. 2017. Providing Affordable Housing for Low-Income People in Indonesia (Development of Model on Housing Law). IJASOS-International E-Journal of Advances in Social Science, Issue 9, Pg. 1094-1103.

Saaty, T.L. 1980. The Analytic Hierarchy Process: Planning, Priority Setting, Resource Allocation. McGraw-Hill: New York, USA.

Sepriyadi, A. 2016. Evaluasi Purna Huni Rumah Susun Sew Pudai di Kota Kendari. (Thesis). Yogyakarta: Universitas Gadjah Mada.

Silas, J. 2001. The Kampung Model. Habitat Debate Vol 7 No.2.

Standart Nasional Indonesia 03-1733-2004 Tentang Tata Cata Perencanaan Lingkungan Perumahan di Perkotaan.

Sudarwanto, B., Padelaki, E., Soetomo, S., 2014. Pencapaian Perumahan Berkelanjutan 'Pemilihan Indikator Dalam Penyusunan Kerangka Kerja Berkelanjutan'. Jurnal MODUL UNDIP Vol. 14, pp. 105-102. DOI: https://doi.org/10.14710/mdl.14.2.2014.105-112.

Sunarti, S., Yuliastuti, N., Indiasjario. 2018. Stakeholder Collaboration in Provision of Housing for Low Income Community in Salatiga City. Jurnal TATA LOKA Planologi Undip Volume 20, pp 455-471. DOI: https://doi.org/10.14710/tataloka.20.4.455-471.

Sunarti, S., Yuliastuti, N. Tyas, W.P., Sari D.P.P. 2020. Housing Facilities Provision in KORPRI Salatiga Housing: Reality and Neighborhood Unit Concept. Jurnal TATA LOKA Planologi Undip Volume 20 (2), pp 249-260. DOI: https://doi.org/10.14710/tataloka.20.2.249-260.

Tam, V.W.Y. 2011. Cost Effectiveness of Using Low Cost Housing Technologies in Construction. Procedia Engineering, Elsevier vol.14: pp 156-160. DOI:10.1016/j.proeng.2011.07.018

Tanuwidjaja, G. Mustakim, Hidayat, M., Sudarman, A. 2009. Integrasi Kebijakan Perencanaan dan Desain Rumah Susun yang Berkelanjutan, dalam Konteks Pembangunan Kota yang Berkelanjutan. Seminar Nasional Universitas Kristen Maranatha, Bandung. Retrieved from http://repository.petra.ac.id/id/eprint/15566.

Tupenaite, Laura., Lill, Irene., Geipele, I., Jurga Naimaciviene. 2017. Ranking of Sustainability Indicators for Assessment of the New Housing Development Projects: Case of the Baltic States. Journal of MDPI Resources 2017, 6,66. DOI:10.3390/resources6040055

Turcotte, David and Geiser, Ken. 2010. A Framework to Guide Sustainable Housing. Housing and Society vol. 37 (2) pp. 87-117.

DOl:https://doi.org/10.1080/08882746.2010.11430582

Turner, John F.C. 1972. Housing by People. London: Marion Boyars Publisher Ltd.

Yakob, Hamizah F.Y., Hazlina Hamdanb. (2012). Land Use Regulations towards a Sustainable Urban Housing: Klang Valley Conurbation. Procedia-Social and Behavioral Sciences 68, 578-589. 
JournalHomepage: http://jurnal.ut.ac.id/reksabumi

Yuwono, Astrid A. 2016. Evaluasi Pasca Huni Bangunan Braga City Walk Bandung. Serat Rupa Journal of Design 1(2):222. DOI:10.28932/srjd.v1i2.451

Zhang, X., Wu, Y., Shen, L., Skitmore, M. 2014. A Prototype System Dynamic Model For Assessing the Sustainability of Construction Projects. International Journal of Project Management 32 pp. 66-76. DOI: https://doi.org/10.1016/j.jproman.2013.01.009

Zimring, C.M., Reizenstein, J.E. 1980. Post-Occupancy Evaluation: An Overview. Environment and Behaviour 12, 429-450. DOI:10.1177/0013916580124002 